\title{
Strengthening the Professionalism of Lecturers Through Improving the Productivities in Publishing Articles
}

\author{
Siti Fathonah ${ }^{1}$, Adhetya Kurniawan ${ }^{2}$, Febrian Arif $B^{3}$, Siti Nurhayati ${ }^{4}$ \\ \{fathonah@mail.unnes.ac.id ${ }^{1}$, adiet000@gmail.com², febrian.arif.budiman@mail.unnes.ac.id ${ }^{3}$ \\ sitiayya55@gmail.com ${ }^{4}$ \} \\ Faculty of Engineering, Universitas Negeri Semarang ${ }^{1,2,3,4}$
}

\begin{abstract}
Professionalism of lecturers is shown by their ability in publishing articles in national and international journals. Journal publications are used for promotion, continuity of teacher certification, and research and service activity outcomes. The research aim to determine the factors that influence the productivity of the publication of the article lecturer of the Engineering Faculty. The research approach uses vacto exposure. The research subjects were $25 \%$ of FT lecturers as many as 38 lecturers. Factors that influence the publication of articles in journals known by structured questionnaire include english proficiency, publication method, administration cost, academic environment. The factors were analyzed by simple regression and multiple regression analysis. The result showed that 1) The productivity factors of publication of journal articles in the category are quite good with details of the average value of english proficiency 3.2, publication methode 3.0, administration cos t3.0, and academic environment 3.4 (maximum score of 5); 2) The four factors partially and synergy significantly influence the productivity of article publications with $\mathrm{p}$ value $=0,000 ; 3$ ) The multiple regression line for the productivity factor of the publication of the journal article $\mathrm{Y}=-0.11+0.242 \mathrm{X} 1+0.260 \mathrm{X} 2+0.259 \mathrm{X} 3+0.243$ $\mathrm{X} 4$. Research suggestions for strengthening professional lecturers require motivation and journal writing workshops with assistance, and the process of providing rewards is carried out thoroughly.
\end{abstract}

Keywords : strengthening the professionalism, lecturers, pubslihing articles

\section{INTRODUCTION}

In the Permenpan (The Regulation of Indonesian Ministry of State Apparatus Utilization) number 17 Year 2003 [1] paragraph 14 about the Functional Position of Lecturer and The Credit Point, the main academic duty of lecturers educating, researching, and conducting community service. The evaluating component for lecturer's academic position is research (including the execution of research and producing scientific/technological/artistic/literary research). Besides, the Regulation of Indonesian Ministry of Research, Technology, and Higher Education Number 20 year 2017 [2] about the Lecturer's Professional Allowance and the Professor's Honorarium Allowance obliges lecturers who have an academic position as a Head Lector and 
Professor to publish scientific research. The paragraph 4 clause 1 mentions that to improve the quality and the quantity of scientific research in Indonesia, in three years, a Head Lector should publish a. minimum three nationally accredited scientific journals; or b. minimum one internationally accredited scientific journal. For a Professor (in paragraph 8 clause 1), they should produce minimum a. three internationally accredited scientific journals; or $b$. one scientific journal in a reputable international journal. The scientific journal is called an article. The article is a text made by students, lecturers, researchers, and scientists in an academic context $[3]$.

Besides, lecturers should have a publication as the output of their scientific activities and community services. The publication should be an article in a nationally accredited/internationally accredited/unaccredited national journal publishing [4]. In two years there is no significant professional improvement of lecturer in the Engineering Faculty. They do not get any accepted funding from the DRPM DIKTI (Directorate General of Research and Development for Higher Education) or DIPA of UNNES (Universitas Negeri Semarang's or the Faculty's Budget Implementation Checklist), except the activities for the community service form the funding of DPRM. In 2018, there are 18 researches and 9 community service proposals funded by DPRM, 18 researches and 7 community service proposals funded by DIPA UNNES, and 70 researches and 58 community service proposals funded by DIPA PNBP of the Faculty. In 2019, the number added into 19 researches and 5 proposals funded by DPRM, 30 researches and 36 proposals to DIPA UNNES, and 73 researches and 56 community services by the DIPA PNBP of the faculty. The total of the activities are added from 2018 to 2019, from180 to 219 . The outputs of these activities are scientific journals, and ISBN proceedings [5] [6].

The obligation for publishing journals to the Lector and Professor is related to the motivation of increasing the quantity and improving the quality of the education in national and international level. The increasing number of the publication in the international and reputable international journal publishings will help Indonesia's academicians to compete with other countries. Currently, the number of scientific journals in Indonesia is lower than many developing nations, even under the neighboring countries, like Malaysia, Singapore, and Thailand.

International publication through scientific journals is a medium of communication between researchers around the world to explain their most recent modern researches. In writing the journal, the authors should use proper writing in English. Moreover, they need two years to publish the journals with a high cost for the publication. The cost will be higher for the publisher which have strong citation index and impact factor, such as Nature and Science, Elsevier, Springer, Blackwell, et cetera. Prior researches found that the low number of the publication is caused by minimum understanding of how to publish, limited sources of funding, impatience in revising, and unsupportive academic environment. There is no any significant problem in the substances of the researches proposed by the authors [7]. Mudasir, a lecturer of the Faculty of Mathematics and Natural Science of UGM, mentions that there is a minimum award or appreciation from the university or faculty to publish. In addition, some articles are rejected due to limited scope, insignificant contribution, inadequate data, weak argumentation, and incorrect methodology [8].

From the problems above, it is known that Lecturers have the obligation to publish journals from the Permenpan Number 17 year 2013, Permenristekdikti Number 20 Year 2017. 
They should also conduct research and hold community services. The lecturers, including the lecturers from the Engineering Faculty are obliged to publish articles in a journal publisher, whether in a national or a reputable international journal. Therefore, this research explores the influencing factors for the productivities of the lecturers in the production issues. From the exploration, the researchers expected to find solutions to strengthen the professionalism of lecturers from Engineering Faculty in publishing international journals.।

\section{RESEARCH METHODOLOGY}

The subject of this research is lecturers of Engineering Faculty in Universitas Negeri Semarang. The researchers used expost facto and causal comparative research to dig the research problems. Then, the researchers describe the findings of the observations. Sugiyono explains that ex post facto is an approach of observing something that has already happened to reveal the influencing factors of it [9].

The authors made a questionnaire which contains the productivity factor of the lecturer in publishing journals. The factors are 1) english proficiency, 2) publication methods, 3) administration cost, and 4) academic environment. The questionnaire is made in the responding scale of 1-5, which are 1) $\mathrm{N} / \mathrm{VP}=$ Nonexistent/Very Poor, 2) $\mathrm{F}=$ fair, 3) $\mathrm{M}=$ =moderate, 4) $\mathrm{G}=$ Good, and 5) $\mathrm{VG}=$ Very Good. Table 1 portrays the classification of the factors.

Table 1. Classification of Lecturers' Productivity Level

\begin{tabular}{|l|l|l|}
\hline \multicolumn{1}{|c|}{ No } & Intervals & \multicolumn{1}{c|}{ Categories } \\
\hline 1. & $1.0-1.8$ & Nonexistent/Very Poor \\
\hline 2. & $1.9-2.6$ & Fair \\
\hline 3. & $2.7-3.4$ & Moderate \\
\hline 4. & $3.5-4.2$ & Good \\
\hline 5. & $4 / 3-5.0$ & Very Good \\
\hline
\end{tabular}

Each factor are mentioned in a description and featured with the minimum and maximum score, average score, and standard of deviation. The researchers measured the influential possibility of the factors with simple regression analysis and multiple regression [10].

\section{Results}

Almost all factors have similar results within the research. All factors which influencing the productivities of lecturers in producing the journals are in the average of 3.0-3.4, or in the category of moderate (Table 2). The highest average is in the indicator of academic environment. The result specifically shows that the facilitation from the faculty exists, but it is not optimum. 
Table 2. The influencing factors to Lecturer's Publishing Productivity

\begin{tabular}{lccccc}
\hline Publishing Productivity Factors & Minimum & Maximum & Rerata & SD & Criterion \\
\hline English Proficiency & 1.0 & 4.5 & $\mathbf{3 . 2}$ & 0.76 & Moderate \\
Publication Methods & 1.0 & 4.5 & $\mathbf{3 . 2}$ & 0.81 & Moderate \\
Administration Cost & 1.0 & 4.5 & $\mathbf{3 . 0}$ & 0.87 & Moderate \\
Academic Environment & 2.1 & 4.6 & $\mathbf{3 . 4}$ & 0.61 & Moderate \\
Publisihing Productivity & 1.5 & 4.4 & $\mathbf{3 . 2}$ & 0.66 & Moderate \\
\hline
\end{tabular}

Lecturers have moderate English proficiency level. They have the average score of 3.1 in the indicator of moderate capability in communicating in English, whether oral or written. However, proper English skills are needed to publish journals. Lecturers should concern on the grammar, formatting, reviewing process, and the plagiation prossibility of it. They usually have a problem in the long reviewing process. They also do not have any interest to send a publication to a predatory journal.

The administration cost for research and community service are usually come from the university funding or private funding. The support of the Engineering faculty are from the availability of online journal and learning sources to lecture. The faculty also supports the lecturers by holding group discussion, providing printed journals, and conducting a workshop for the lecturers. Somehow, the lecturers are not taking full advantage of it. They were also not taking the advantage from the helps of their peers.

The result of the simple and multiple regression analysis showed the significance of 0.000 . The number shows that all indicators influence the publication number of journals. The coefficient of regression to each indicator are 0.660 for English proficiency, 0.759 for publication method, 0.696 for the administration cost, and 0.832 for the academic environment. The multiple regression obtained the constanta of 0.11 , which means that the additional score in each criterion will decrease the score in 0.11 .

Table 3. The result of Simple Regression and Multiple Regression Analysis for the Factors of Publishing Productivity in Engineering Faculty

\begin{tabular}{lccc}
\hline Factors of Publishing Productivity & Sig partial & Sig synergy & Regression line \\
\hline English Proficiency & 0.00 & 0.00 & $\mathrm{Y}=1.114+0.660 \mathrm{X}_{1}$ \\
Publication Method & 0.00 & 0.00 & $\mathrm{Y}=0.790+0.759 \mathrm{X}_{2}$ \\
Administration Cost & 0.00 & 0.00 & $\mathrm{Y}=1.095+0.696 \mathrm{X}_{3}$ \\
Academic Environment & 0.00 & 0.00 & $\mathrm{Y}=0.357+0.832 \mathrm{X}_{4}$ \\
Multiple Regression & $\mathrm{Y}=-0.11+0.242 \mathrm{X}_{1}+0.260 \mathrm{X}_{2}+0.259 \mathrm{X}_{3}+0.243 \mathrm{X}_{4}$ \\
\hline
\end{tabular}


The regression line in Table 3 is portrayed in Figure 1. The factors have same pattern in a positive way. They have similar level of coefficient of regression $(0.66-0.83)$. The highest criterion is English proficiency as the most dominant (1.114) one in influencing the publication of articles, followed by the administration cost (1.095). The value of Adjusted R square is 0.997 , which means that $99.7 \%$ productivity of publication is explained from the English proficiency, publication method, administration cost, and academic environment.
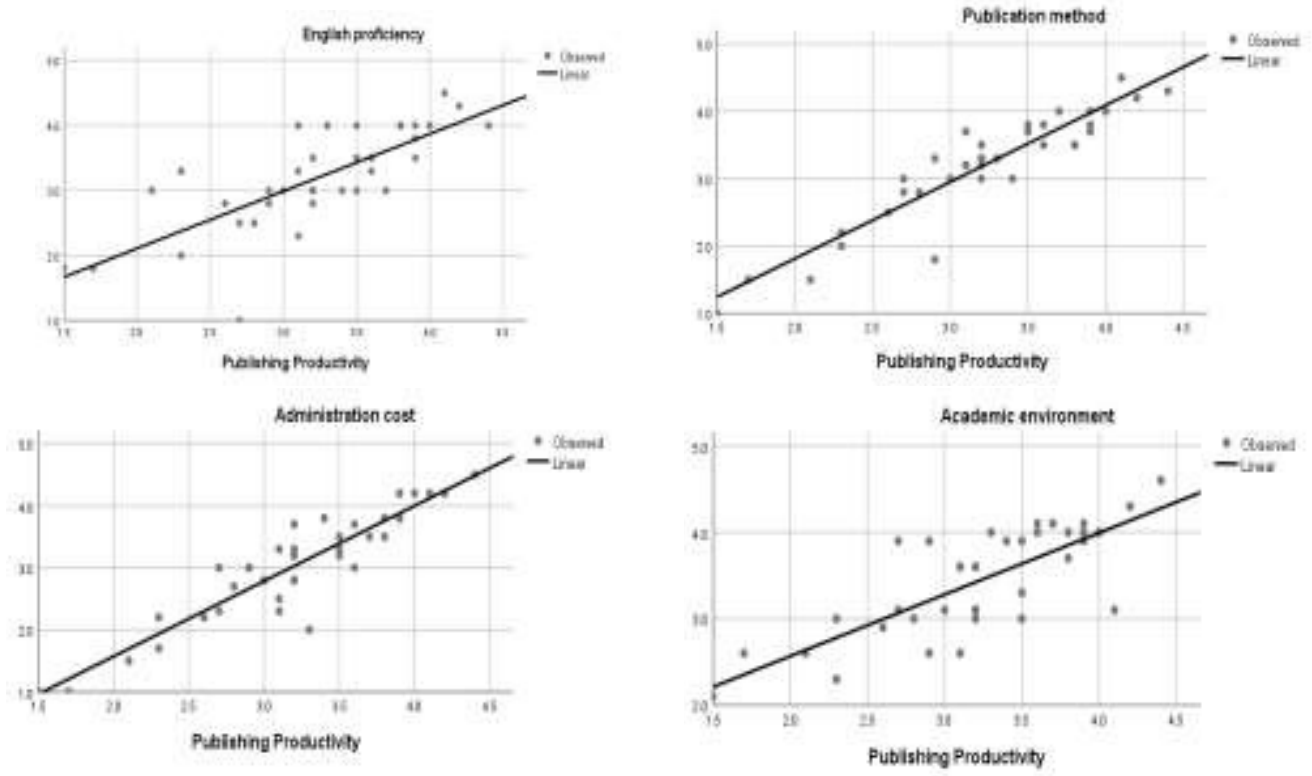

Figure 1. Simple Regression Line for each indicator (English proficiency, publication method, administration cost, academic environment) with the factor of Publishing Productivity

\section{Discussion}

The lecturers in Engineering Faculty scored 3.1 in terms of English proficiency. They have a moderate English level, however, they do not apply it into their daily life. They should habituate writing in English at university. According to Spira, a language which is known by most people nowadays is English; therefore, people should use it as early as possible [11]. A research by a young urologist in Turkey shows that English proficiency and high level of publication is in line with the improvement of academic career [12]. English proficiency is highly needed in publishing articles. A research in Southern America proves that the lack of English proficiency can cause a lost of science in a workshop called as "English-Language Publication for Nonnative English Speakers" [13].

Engineering lecturers in UNNES do not send their paper to a predatory publisher. It is proven with the average score of 2.6. The condition should be maintained. Predatory journal is a publishing of journal which exploits the author. It opens a chance for the predator to charge 
money for their service without any proceeding steps (expert judgement, editing, archiving, and indexation). The writer can send the journal into predatory publisher without concerning the quality of the journal. All lecturers in the faculty are recommended to choose publisher with a reputation of open access [14]. The impact factor of journal is important to academician [15] (Binns and Low, 2019).

The lecturer from Engineering faculty has already done anti-plagiarism check. They scored 3.4 or moderately good. The score reflects that the lecturers have the integrity to do that. Based on Suter and Suter [16] plagiarism can break the career of the writer. For an amateur writer, plagiarism is always be a problem in beginning their career.

The academic environment of Faculty of Engineering is moderately good. The environment is supportive for the lecturer to be productive in publishing articles. As in Bonaccorsi [17], a scientific community results valid knowledge in an evaluative and productive way. Besides, Binns and Low [15] suggests to evaluate the strategy of communication and publication of journal to be advantageous for the society in general. Apart from the support, there should be a workshop for the lecturers in academic writing. The result of a research in the formal postdoctoral program shows that there should be a clinical and translational knowledge given to the lecturer to improve their academic productivity in significant way in the speed of $\mathrm{p}=$ 0.002 and $\mathrm{H}$-index of $\mathrm{p}=0.013$ [18]. Internet access is also important to browse relevant journals. Irawan et al [19] says that Indonesian journal should improve its accessibility, quality, and relevance for the sake of scientific development in the society, industry, and government.

All the factors above are supporting the publication level of lecturers. The factors should be supported continuously and constantly. Besides, lecturers should be active communicating in English whether in verbal or written to support their publishing level. Meanwhile, the faculty can help their environment by providing them with fast internet access. Personally, lecturers should be patient and persevering in applying journal's formatting until they got their article published. The final publication can make lecturers more confident to write more article which eventually increase the number of invention [20]

Funding is a vital thing for a research and community service. The element allows all lecturers to do these obligations. The idea is relevant to the example of research about Benign Prostatic Hyperplasia (BPH). Due to excessive support, many articles about BPH can help the society [21]. Rewarding is important to motivate lecturers to publish in a reputable international publisher. The process of it should be careful only based on the merit.

They should be developed to optimize the publication in maximum level. The other research regarding publication shows that the obstacles of journal production are burdening working load, high administration price, limited subscription of printed journal, limited subscription of online journal, and limited access to printed journal [22]. The lack of technological understanding also inhibits lecturer to publish scientific journal [23]. 


\section{CONCLUSION}

All the productivity factors (English proficiency, publication method, administration cost, academic environment) of article publication by Engineering Faculty's lecturers are moderately good. These factors have partial and synergical influence in the value of $p=0.000$. The research also results the simple regression line on the multiple regression factor of $\mathrm{Y}=$ $0.11+0.242 \mathrm{X} 1+0.260 \mathrm{X} 2+0.259 \mathrm{X} 3+0.243 \mathrm{X} 4$.

Based on the result, it is suggested to 1) motivate the lecturers to be active in writing articles, 2) provide workshop of article writing and journal publication for the lecturers, and reward the lecturers who published carefull

\section{REFERENCES}

[1] Kementerian Pendayagunaan Aparatur Negara Dan Reformasi Birokrasi. Peraturan Menteri Pendayagunaan Aparatur Negara Dan Reformasi Birokrasi Nomor 17 Tahun 2013. Tentang Jabatan Fungsional Dosen Dan Angka Kreditnya. Jakarta : Kemenpan (2013).

[2] Kementerian Riset, Teknologi, dan Pendidikan Tinggi. Nomor 20 Tahun 2017 Tentang Pemberian

Tunjangan Profesi Dosen Dan Tunjangan Kehormatan Profesor. Jakarta: Kemenristekdikti (2018). [3] Abdullah, A.G. Dari Riset sampai Naskah. Bandung : Rumah Publikasi Indonesia (2019).

[4] Kementerian Riset, Teknologi, dan Pendidikan Tinggi. Panduan Penelitian dan Pengabdian Kepada Masyarakat Edisi XII. Jakarta: Kemenristekdikti (2018).

[5] Lembaga Penelitian dan Pengabdian Kepada Masyarakat. Rekapitulasi \& Daftar Penelitian Dan Pengabdian

Kepada Masyarakat 2018. Semarang : LP2M (2019)

[6] Lembaga Penelitian dan Pengabdian Kepada Masyarakat. Rekapitulasi \& Daftar Penelitian Dan Pengabdian

Kepada Masyarakat 2019. Semarang : LP2M (2019).

[7] Satria, A. Seputar Menulis Di Jurnal Internasional. Jurnal Pustakawan Indonesia. 10(2) : 36-37. http://garuda.ristekdikti.go.id/documents/detail/ 85909 (2010).

[8] Politeknik Negeri Padang. Kondisi Dosen Peneliti Indonesia Sekarang : Publikasi Rendah, Utang Banyak. http://www.pnp.ac.id/pp=3208 (2019).

[9] Sugiyono. Metode Penelitian Pendidikan (Pendekatan Kuantitatif, Kualitatif dan R\&D). Bandung: Alfabeta

(2007)

[10] Kadir. Statistika Terapan. Jakarta: RajaGrafindo Persada (2015).

[11] Spira, A. There is room for different languages in public health journals. European Journal of Public

Health. 20 (3): 245- 246, https://doi.org/10.1093/eurpub/ckq050 (2010).

[12] Resorlu, B., M. S. Silay, K. Onem, O. Bayrak, A. E. Sonbahar, O. Acar, O. Ergun, O. Celik, T. Tefik, F.

Firdolas, and Z. Tandogdu. Factors Influencing Young Urologists' Productivity and Academic Career 
Choice. Urologia Journal, 83 (1): pp. 31-35 (2015).

[13] Fradkin, C. Scientific Publication for Nonnative English Speakers: A Retrospective of a Workshop in

Brazil. Science Communication, 39 (3): pp. 395-403 (2017).

[14] Masten, Y. and A. Ashcraft. Due diligence in the open-access explosion era: choosing a reputable journal for publication. FEMS Microbiology $\quad$ Letters. $364 \quad$ (21). https://doi.org/10.1093/femsle/fnx206 (2017).

[15] Binns, C. and W. Y. Low. Publish or the Population Perishes: The Challenges of Regional Publishing in Public Health. Asia Pacific Journal of Public Health, 31 (5): pp. 396-403 (2019).

[16] Suter, W.N. and P. M. Suter. Understanding Plagiarism. Home Health Care Management \& Practice, 30

(4): pp. 151-154 (2018)

[17] Bonaccorsi, A. Towards an Epistemic Approach to Evaluation in SSH. The Evaluation of Research in

Social Sciences and Humanities. pp 1-29 (2018).

[18] Ehlers, S.L., K. E. Cornelius, A. J. Greenberg-Worisek, D. O. Warner, K. M. Weavers, K. R. Thomson, M.

J. Hansen, J. J. Larson, F. T. Enders, and P. G. Iyer. A matched cohort examination of publication rates among clinical subspecialty fellows enrolled in a translational science training program. Journal of Clinical and Translational Science. 2 (5) (2018).

[19] Irawan, D. Erwin, Abraham, Juneman, Multazam, M. Tanzil, Rachmi, C. Novianti, Mulyaningsih, Indrya, Viridi, Sparisoma, Mukti, R. Rakhmata, Djamal, Mitra, Puradimaja, D. Juanda. 2018. Era baru publikasi di Indonesia: status jurnal open access di Directory of Open Access Journal (DOAJ). Berkala Ilmu Perpustakaan dan Informasi. 14 (2).

[20] Selfe, T.K. How to write your first scholarly journal article using reporting guidelines as a template.

Journal of Clinical and Translational Science. 3 (1) (2019).

[21] Cruz, A. P., C. Ellimoottil, C. A. Dauw, T. A. Skolarus. Characterizing the top 100 articles in benign prostatic hyperplasia literature using bibliometric analysis. Journal of Clinical and Translational Science. 3 (1) (2019).

[22] Pardjono, Nuchron, Surono, Ramdani, D. Sulaeman . Analisis Faktor-Faktor Penghambat Produktivitas Publikasi Karya Ilmiah Mahasiswa PPs UNY pada Jurnal Internasional Terindeks. Jurnal Dinamika Vokasional Teknik Mesin. 2 (2) (2017).

[23] Julianto, Very. Faktor-faktor penghambat meningkatnya publikasi di Pogram Studi Psikologi UIN Sunan

Kalijaga Jogjakarta. Jurnal Psikologi Integratif, 6(2), 131-140 (2018). 